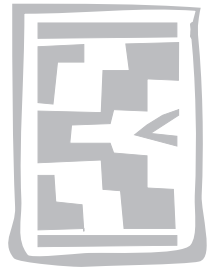

\title{
Gastric nematodes of Nile crocodiles, Crocodylus niloticus Laurenti, 1768, in the Okavango River, Botswana
}

\author{
K. JUNKER ${ }^{1}$, K. WALLACE ${ }^{2}$, A.J. LESLIE ${ }^{2}$ and J. BOOMKER ${ }^{1 *}$
}

\begin{abstract}
JUNKER, K., WALLACE, K., LESLIE, A.J. \& BOOMKER, J. 2006. Gastric nematodes of Nile crocodiles, Crocodylus niloticus Laurenti, 1768, from the Okavango River, Botswana. Onderstepoort Journal of Veterinary Research, 73:111-114

The ascaridoid nematodes Dujardinascaris madagascariensis Chabaud \& Caballero, 1966, Dujardinascaris dujardini (Travassos, 1920), Gedoelstascaris vandenbrandeni (Baylis, 1929) Sprent, 1978 and Multicaecum agile (Wedl, 1861) Baylis, 1923 were recovered from the stomach contents of Crocodylus niloticus Laurenti, 1768 from the Okavango River, Botswana, together with Eustrongylides sp., a dioctophymatoid nematode usually parasitizing piscivorous birds. Dujardinascaris madagascariensis was present in most of the infected hosts, while the remaining species were mostly represented in single collections in one to three hosts. All four ascaridoid nematodes represent new geographic records.
\end{abstract}

Keywords: Ascaridoidea, crocodilians, Crocodylus niloticus, nematodes, Nile crocodiles

\section{INTRODUCTION}

A number of gastrointestinal nematodes from crocodilian hosts have been reported in the literature (Baker 1983). Amongst these the ascaridoid nematodes belonging to the subfamily Heterocheilinae and Anisakinae are some of the most prominent species (Sprent 1977, 1978, 1979a, b).

Eight of the 11 genera are included in the subfamily Heterocheilinae parasitize crocodilians, namely Brevimulticaecum Mozgovoy, in Skrjabin, Shikhobalova \& Mozgovoy, 1952, Dujardinascaris Baylis, 1947, Gedoelstascaris Sprent, 1978, Hartwichia Chabaud \&

* Author to whom correspondence is to be directed. E-mail: jboomker@op.up.ac.za

1 Department of Veterinary Tropical Diseases, University of Pretoria, Private Bag X04, Onderstepoort, 0110 South Africa

2 Department of Conservation Ecology, University of Stellenbosch, Private Bag X1, Matieland, 7602 South Africa

Accepted for publication 16 March 2006-Editor
Bain, 1966, MulticaecumBaylis, 1923, Ortleppascaris Sprent, 1978, Trispiculascaris Skrjabin, 1916 and Typhlophorus Von Linstow, 1906 (Sprent 1983). The genus Terranova Leiper \& Atkinson, 1914 is included in the subfamily Anisakinae (Sprent 1979a).

The genera Hartwichia and Trispiculascaris have as yet only been recorded from the African continent, while Brevimulticaecum occurs in South and North American crocodilians, and Typhlophorus seems exclusive to India. Gedoelstascaris and Multicaecum have both been found in Africa and Australasia, whereas Ortleppascaris is known from African as well as South and North American hosts.

To date, Terranova and Dujardinascaris are the only ascaridoid genera occurring throughout the entire range of the crocodilians' geographic distribution, with representatives in the Neotropics, Africa and Australasia (Sprent 1977, 1978, 1979a, b, 1983). Even genera with a wide geographic distribution are generally characterized by strict species separation with respect to the various geographic areas. Multi- 
caecum agile (Wedl, 1861) Baylis, 1923 and Terranova crocodilii (Taylor, 1924) Hartwich, 1957, in fact, are the only two species that have been listed from Africa as well as Australia.

In this paper we report on some nematodes recovered from the stomach contents of Nile crocodiles, Crocodylus niloticus Laurenti, 1768, in Botswana.

\section{MATERIAL AND METHODS}

During August 2003 to August 2005 a study was conducted by one of us (K. Wallace) on the composition of the diet of Nile crocodiles from the Okavango River, Botswana. The stomach contents of the crocodiles were pumped into separate containers and macroscopically examined. Nematodes present in these contents were collected and fixed in $70 \%$ ethanol. They were subsequently cleared in lactophenol and identified using the descriptions of the authors listed below. Nematodes were recovered from 57 crocodiles.

The results compiled herein are not based on a complete collection of the helminth parasites, for which the hosts would have had to be sacrificed, but represent incidental findings from the stomach contents of the various crocodile hosts.

\section{RESULTS}

The ascaridoids Dujardinascaris madagascariensis Chabaud \& Caballero, 1966, Dujardinascaris dujardini (Travassos, 1920), M. agile and Gedoelstascaris vandenbrandeni (Baylis, 1929) Sprent, 1978 were recovered from the crocodiles. One male and one female specimen of the dioctophymatoid genus Eustrongylides Jägerskiöld, 1909 were present in a single host.

Helminth diversity was low in the Nile crocodiles examined, with the genus Dujardinascaris being the mostcommonly encountered. Dujardinascaris madagascariensis was recovered from most of the infected hosts, while the remaining species, $D$. dujardini, $G$. vandenbrandeni and $M$. agile, only occurred in a few (1-3) of the crocodiles.

The majority of the crocodiles (46) were only parasitized by one ascaridoid species, usually Dujardinascaris madagascariensis. Two of the ascaridoid species were present at the same time in only six hosts. Multiple infections with more than two species per host were not encountered.

\section{DISCUSSION}

While it is difficult to distinguish between some of the females of the various Dujardinascaris spp., $D$. madagascariensis is distinct from the other four African species in that the vagina opens through a distinct papilla between the lips of the vulva. In some of our specimens remains of copulatory cement could still be observed on the papilla. The majority of the male specimens were assigned to $D$. madagascariensis on the basis of the length of their spicules. The spicules of $D$. dujardini are distinctly longer than those of $D$. madagascariensis, whereas the spicules of both Dujardinascaris gedoelsti Sprent, 1977 and Dujardinascaris puylaerti Sprent, 1977 are considerably shorter (Sprent 1977). Dujardinascaris petterae Sprent, McKeown \& Cremin, 1998 has short, unequal spicules (Sprent, McKeown \& Cremin 1998). A single male specimen possessed the typical trifurcate gubernaculum of $D$. dujardini and a single female with a sinuous vagina, but without a vaginal papilla was assigned to the same species.

All the parasites reported in this study have previously been reported from crocodiles.

Dujardinascaris dujardini has been recorded from $C$. niloticus and Crocodylus cataphractus from Africa, as well as from Crocodylus porosus in India (Yamaguti 1961). Sprent (1977) lists "crocodile" as its type host and the Nile crocodile as additional host from Zambia and the Democratic Republic of the Congo. More recently, $D$. dujardini was reported from $C$. niloticus from Egypt (El-Dien Mahmoud 1999). Dujardinasceris madagascariensis is listed from $C$. niloticus and C. cataphractus in Madagascar, Angola and the Democratic Republic of the Congo (Sprent 1977). However, the recovery of $D$. dujardini and $D$. madagascariensis from crocodiles in Botswana represents a new geographic record for these parasites.

Three additional representatives of the genus Dujardinascaris have been reported from the African continent. Sprent et al. (1998) described D. petterae from Osteolaemus tetraspis in the Congo. Dujardinascaris gedoelsti Sprent, 1977 and D. puylaerti Sprent, 1977 were collected from C. niloticus in the Republic of the Congo (Sprent 1977). The latter species was also present in Zambia (Sprent 1977). None of the above three species was recovered from crocodiles in Botswana.

Gedoelstascaris vandenbrandeni is one of two species that Sprent (1978) removed from the genus $D u$ jardinascaris and placed in a new genus, namely Gedoelstascaris. Gedoelstascaris vandenbrandeni 
occurs only in African crocodiles and has been recorded from $C$. niloticus and $C$. cataphractus in Angola, Zambia and the Democratic Republic of the Congo. Its Australian counterpart, Gedoelstascaris australiensis (Baylis 1931) Sprent, 1978, parasitizes Crocodylus johnstoni and C. porosus and has been found in hosts from Australia as well as the Solomon Islands (Sprent 1978). There are no previous records of $G$. vandenbrandeni in Botswana.

Of the four ascaridoid nematodes found in this study, $M$. agile is the only one with a geographic distribution extending beyond the African continent and utilizing hosts other than African crocodilians. Its type host is $C$. niloticus from Egypt, but it has also been recovered from $C$. cataphractus and was recorded from the Republic of the Congo, Zambia and Zimbabwe. Hosts from the Australasian region are C. palustris, C. johnstoni and Gavialis gangeticus. India and Australia are listed as localities (Sprent 1979b). Botswana constitutes a new geographic record for M. agile.

Literature regarding the prevalence and intensity of gastric nematode infections in crocodiles and alligators is scant and the data on both are somewhat variable (Cherry \& Ager 1982; Ladds \& Sims 1990; Goldberg, Bursey \& Aquino-Shuster 1991). The latter might be explained by the fact that not many concise studies regarding the gastric nematode fauna of crocodilians have been conducted and findings often represent the data from few or single hosts.

Ladds \& Sims (1990) report a prevalence of $41 \%$ for Dujardinascaris mawsonae Sprent, 1977 in young crocodiles belonging to two species, $C$. porosus and Crocodylus novaeguineae, in Papua New Guinea. The range of intensity of infection is given as 1-20, but as many as 60 and 100 worms were recovered from two crocodiles in good condition. Histological examination of the gastric wall revealed the presence of Capillaria sp. in $60 \%$ of the hosts.

Dujardinascaris waltoni Sprent, 1977 was the only nematode parasite present in Alligator mississippiensis in South Florida. It was collected from $93 \%$ of the hosts and the mean intensity of infection was high $(89 \%)$, with a maximum burden of 413 specimens per alligator (Cherry \& Ager 1982).

Contrary to our findings, Dujardinascaris was the least prevalent ascaridoid genus in Caiman yacare in Paraguay, but was nevertheless the one with the highest mean intensity of infection. Brevimulticaecum baylisi Travassos, 1933 had the highest prevalence followed by Ortleppascaris alata Baylis, 1947 (Gold- berg et al. 1991). The genus Brevimulticaecum is exclusive to caimans and alligators in the New World (Sprent 1979). The genus Ortleppascaris is represented in Africa by a single species, Ortleppascaris nigra Gedoelst, 1916 from C. niloticus and C. cataphractus (Sprent 1978), but was not present in the crocodiles in Botswana.

No clear picture regarding the occurrence of multiple infections with ascaridoid nematodes emerges from the literature. Some authors report single species infections (Cherry \& Ager 1982; Ladds \& Sims 1990), while others list three or four species, without, however, specifying how many of these were recovered per individual host (Goldberg et al. 1991; Scott, Simcik \& Craig 1997). Scott et al. (1997) examined the helminth fauna of 50 American alligators and came to the conclusion that the infracommunity structure was "depauperate when compared to homoiothermic hosts", a statement which complies with the well documented fact that the helminth diversity of reptiles, in general, is less pronounced than that of mammalian and avian hosts (HeringHagenbeck \& Boomker 2000).

With the exception of Eustrongylides sp., all the parasites were collected from their typical predilection site in the host, but $D$. dujardini, D. gedoelsti and $G$. vandenbrandeni have also been reported from the intestine (Sprent 1977; Sprent et al. 1998). The genus Eustrongylides occurs in the wall of the proventriculus of its piscivorous avian final hosts and utilizes fish as intermediate hosts (Measures 1987).

Little is known about the life-cycle of any of the parasites found during this study, but fishes seem to play an important role as intermediate hosts of all the species (Sprent 1977, 1978, 1979a, b). Studies on the stomach contents of Nile crocodiles reveal a significant change in their feeding habits as the individuals grow larger. Despite this ontogenetic food-shift, fish remain one of the most important dietary items throughout the crocodiles' lifespan. Fish were found in the stomachs of $60 \%$ of crocodiles ranging from 2.5-3.0 $\mathrm{m}$ in total length, and fish were still recovered from nearly $40 \%$ of specimens $>4.5 \mathrm{~m}$, (Ross 1989; Alderton 1992). As one of the main prey items, fish would appear to be the intermediate host of choice to ensure the successful completion of the life-cycle of these gastric nematodes.

\section{ACKNOWLEDGEMENTS}

This study was made possible by a grant to A.J. Leslie by the National Research Foundation and the 
Earthwatch Institute, USA. We thank the Department of Wildlife and National Parks, Botswana and the Ministry of Environment, Wildlife and Tourism, Botswana. Our thanks also go to Pertec International and the entire Okavango Crocodile Project field team.

\section{REFERENCES}

ALDERTON, D. 1999. Crocodiles and alligators of the world. London: Cassel plc.

BAKER, M.R. 1983. Nematode parasitism in amphibians and reptiles. Canadian Journal of Zoology, 62:747-757.

CHERRY, R.H. \& AGER, A.L. 1982. Parasites of American alligators (Alligator mississippiensis) in South Florida. Journal of Parasitology, 68:509-510.

EL-DIEN MAHMOUD, N.E. 1999. Crocodiles as a source of nematode larval infestation among fish species in Lake Naser, Egypt (with 9 figures). Assiut Veterinary Medical Journal, 40: 88-102.

GOLDBERG, S.R., BURSEY, C.R. \& AQUINO-SHUSTER, A.L. 1991. Gastric nematodes of the Paraguayan caiman, Caiman yacare (Alligatoridae). Journal of Parasitology, 77:1009-1011.

HERING-HAGENBECK, S.F.B.N. \& BOOMKER, J. 2000. A check-list of the nematode parasites of South African Serpentes (snakes) and Sauria (lizards). Onderstepoort Journal of Veterinary Research, 67:1-13.

LADDS, P.W. \& SIMS, L.D. 1990. Diseases of young captive crocodiles in Papua New Guinea. Australian Veterinary Journal, 67:323-330.
MEASURES, L.N. 1988. Revision of the genus Eustrongylides Jägerskiöld, 1909 (Nematoda: Dioctophymatoidea) of piscivorous birds. Canadian Journal of Zoology, 66:885-895.

ROSS, C.A. (Ed.). 1989. Crocodiles and alligators. London: Meerehurst Press.

SCOTT, T.P., SIMCIK, S.R. \& CRAIG, T.M. 1997. Endohelminths of American alligators (Alligator mississippiensis) from southeast Texas. Journal of the Helminthological Society of Washington, 64:258-262.

SPRENT, J.F.A. 1977. Ascaridoid nematodes of amphibians and reptiles: Dujardinascaris. Journal of Helminthology, 51:251285.

SPRENT, J.F.A. 1978. Ascaridoid nematodes of amphibians and reptiles: Gedoelstascaris n.g. and Ortleppascaris n.g. Journal of Helminthology, 52:261-282.

SPRENT, J.F.A. 1979a. Ascaridoid nematodes of amphibians and reptiles: Terranova. Journal of Helminthology, 53:265282.

SPRENT, J.F.A. 1979b. Ascaridoid nematodes of amphibians and reptiles: Multicaecum and Brevimulticaecum. Journal of Helminthology, 53:91-116.

SPRENT, J.F.A. 1983. Ascaridoid nematodes of amphibians and reptiles: Typhlophorus, Hartwichia and Trispiculascaris. Journal of Helminthology, 57:179-189.

SPRENT, J.F.A., MCKEOWN, E.A. \& CREMIN, M. 1998. Dujardinascaris spp. (Nematoda: Ascaridoidea) in Old World crocodilians. Systematic Parasitology, 39:209-222.

YAMAGUTI, S. 1961. The nematodes of vertebrates. Volume III, Part I \& II, in Systema Helminthum. New York: Interscience Publishers. 